\title{
All That Glitters: Devaluing the Gold Standard in the Utopias of Thomas More, Francis Bacon, and Margaret Cavendish
}

\author{
CATHERINE GIMELLI MARTIN \\ University of Memphis
}

Francis Bacon's and Margaret Cavendish's ideal societies unexpectedly follow Thomas More's Utopia in eliminating the exchange value of gold and replacing it with a knowledge economy. Bacon's New Atlantis (1627) and Cavendish's Blazing World (1666) similarly pursue new "light" and shun selfish profit, private trade, capital accumulation, and conspicuous consumption. Unlike More, they allow gold to retain its traditional decorative and symbolic functions, but its "use value" completely trumps its exchange value. Cavendish uses gold to construct and glorify her Blazing World and to forge astonishing defensive weapons, but it cannot be bought, sold, or even earned since it remains exclusively imperial. Bacon restricts gold to buying new "light" or knowledge and honouring thriving families with symbolic golden grape clusters, but like the Fathers of Salomon's House, all three societies value only beneficial knowledge and the collaborative virtues taught by their new or improved religions to further universal peace and brotherhood.

Les sociétés idéales imaginées par Francis Bacon et Margaret Cavendish emboîtent étonnamment le pas à l'Utopie de Thomas More lorsqu'elles éliminent la valeur monétaire de l'or pour la remplacer par une économie du savoir. La New Atlantis de Bacon (1627) et le Blazing World de Cavendish (1666) proposent de façon comparable la quête d'une nouvelle lumière et le refus du profit égoïste, du commerce privé, de l'accumulation du capital et de la consommation ostentatoire. Toutefois, à la différence de More, ils permettent que soit maintenue la valeur esthétique et symbolique de l'or, qui éclipse ainsi complètement sa valeur de monnaie d'échange. Cavendish utilise l'or pour construire et glorifier son univers flamboyant et pour créer d'étonnantes armes défensives, mais il ne peut être ni acheté, ni vendu, ni même gagné, puisqu'il est exclusivement impérial. Bacon limite l'usage de l'or à l'achat d'une nouvelle lumière, c'est-à-dire de la connaissance, et à l'hommage des familles florissantes en leur offrant de symboliques grappes de raisins en or, mais tout comme les Pères de la Maison de Salomon, cettes trois sociétés valorisent uniquement la connaissance bénéfique et les vertus de collaboration qu'enseignent leur religion nouvelle et améliorée afin de favoriser la paix universelle et la fraternité.

"A king who wants to maintain an army can never have too much gold." Thomas More, Utopia 
W Then Thomas More's Utopia (1516, English translation 1551) restated the conventional military wisdom encapsulated in the epigraph above, the main point was to examine Raphael Hythloday's contention that gold's usefulness in warfare rapidly progresses into what moderns might call its "fetishization," its departure from any concrete "use value" as it becomes an end in itself. Its possession automatically confers not just actual buying potential but a quasi-mystical status on the rich and powerful, which thereby permits them to dominate nearly all social discourses and dictate society's goals, the most prestigious of which are oriented toward gaining more gold. Only Hythloday's cleverly unconventional Utopians avoid the often-tragic error of supposing that gold is intrinsically valuable and honourable by denying it any status aside from "pure" self-defense. They use it almost exclusively to purchase mercenary soldiers to conduct their wars, which they consider so dehumanizing that they avoid fighting at all cost; or to put it more accurately, the considerable cost of war is paid by their own labour and the abundant goods produced by their socialist economy, which requires only a relatively short, six-hour work day for all. They have abolished private property, but they encourage limited forms of private endeavour and unpaid self-improvement, which helps refine their arts, crafts, and general and technical knowledge. Yet gold and all other status symbols traditionally associated with achievement are not only socially shunned but vilified, partly by reserving gold solely for ignoble products such as chains for slaves and chamber pots, and partly by reserving jewels for children's playthings. Since all citizens' basic needs are satisfied by their communal state, they derive personal pleasure chiefly from simple bodily enjoyments and pride in their crafts, whether manual, technical, or intellectual. As a result, Hythloday's Utopians have successfully traded a capitalist or profitbased money economy for a far more widely varied knowledge economy in which everyone gains unprecedented levels of health, military security, and knowledge-as-power, as Francis Bacon would later put it. All the disadvantages of social competition based on greed for gold and related objects of conspicuous but essentially useless consumption become laughable, so that except for conducting and, ideally, discouraging warfare, Utopia's rulers actually can have too much gold - a worthless object with little if any use value whenever no wars threaten them.

After More, Europe and particularly England witnessed an explosion in the utopian literary genre, although few participants in that genre adopted 
More's solution to capitalist competition and the growing poverty for which it was often blamed throughout the sixteenth and seventeenth centuries. ${ }^{1}$ More himself rightly traced the decline in the average person's wealth and well-being to a rise in commercial trade at the expense of agriculture, which made staple foods relatively more expensive than the luxury goods increasingly available through England's growing import/export industry. ${ }^{2}$ This crisis was by no means caused by the gold standard per se-which, at the time, was actually a gold and silver standard of exchange-but rather by the rapid rise in prices, which punished the poor, aided the rich, and thus vastly increased income inequality. Another problem cited by historians obeyed the popular maxim that "bad money drives out good": the illegal clipping or debasing of gold and silver coins led to hoarding newer and hence more valuable money, all of which was still made of precious metals. ${ }^{3}$ In general, these economic woes arose due to the incipient rise of capitalism within a still feudal, agrarian system as yet incapable of accommodating the enormous political and legal changes true capitalism would require, and of which on Christian moral grounds alone, More would never approve.

Hence Utopia's solution to these problems is the antithesis of capitalism: wholly eliminating monetary exchange or private gain among citizens and valuing only useful staples no one would hoard if assured of receiving his or

1. On the vast proliferation of utopian political writing, see especially Robert Appelbaum, Literature and Utopian Politics in Seventeenth-Century England (Cambridge: Cambridge University Press, 2002). More was hardly alone, of course, in advocating various forms of socialism or communism, but his socialism was more secular than that of later writers as well as more materially innovative. Other advocates for the poor, like Gerrard Winstanley, were both far more explicitly Christian and peasant- or labour-oriented in outlook, while like Plato before him, More places elite intellectuals at the head of his society's organization, as do most of the non-socialist members of the Hartlib Circle, with some important differences. On Winstanley, see Appelbaum, 153-71; on the Hartlib Circle, Gabriel Platte, and other "ameliorists" who offer only very limited and "specific material recommendations" (118) to address scarcity and promote world peace, see Appelbaum, 116-25. As he details, all of the above rely far more on millenarian expectation than on the thorough reorganization of society and its values found in the utopists considered here.

2. See Jan de Vries, "The Economic Crisis of the Seventeenth Century after Fifty Years," Journal of Interdisciplinary History 40.2 (Autumn, 2009): 151-94, 189, 165. De Vries usefully corrects and updates assumptions formerly tied to Marxist Theory.

3. Stephen Deng, Coinage and State Formation in Early Modern England (New York: Palgrave Macmillan, 2011), 10. 
her due portion. By additionally abolishing social classes and requiring all but the disabled and a small scholarly elite to contribute to agriculture and basic manufacturing, such a society would easily accumulate sufficient surpluses to exchange for gold dedicated solely to the common national interest, here defined as self-defense. Yet while the same problems that troubled More were widely recognized, utterly rejecting the gold standard in favour of a highly centralized, state-supported knowledge economy impressed only a small handful of later writers. As this article argues, the most prominent and important of these were Sir Francis Bacon, James I's former Lord Chancellor, and Margaret Cavendish, Duchess of Newcastle. ${ }^{4}$ Neither of these two very different if almost equally eccentric utopists follows More in turning gold into an ignoble metal fit only for buying mercenaries and other "shameful" uses, but both demote gold's exchange value and promote its use value in strikingly parallel if still idiosyncratic ways. Cavendish's A Description of a New World, called the Blazing World (1666) turns gold into a non-exchangeable building material as well as a symbol of royalty forbidden to commoners, who, as the fictional More and his Hythloday agree, ordinarily compete in furthering the king's virtually endless quest for gold, and of course, gaining some for themselves. Cavendish's rigid class system effectively eliminates that kind of competition, while Bacon's New Atlantis (1627) creates a knowledge economy based on stable divisions of labour that turn competition into something more like the collaborative self-improvement found in More's Utopia. The advantages of this system are most clearly on display in Bacon's central scientific institution, Salomon's House.

Yet perhaps more startling still, both Bacon and Cavendish not only continue More's economic critique but join him in disdaining any form of militarism or nationalism that serves only the selfish interests of kingly pride and expansionist greed. Partly to correct that problem, they similarly create "reformed" religions that discourage competition and unite their citizens behind their true self-interests: peace, brotherhood, stability, and tolerance, which as in More, provide the true path to both individual and social salvation. More's utopian religion is usually understood as a moralistic form of Epicureanism,

4. I am not the first to consider these three utopias in conjunction, but Marina Leslie's book featuring all three examines their relation to history only in material and not in the economic, military, or religious terms explored here. See Leslie, Renaissance Utopias and the Problem of History (Ithaca, NY: Cornell University Press, 1998). 
while both Bacon's and Cavendish's religions rely on Christian revelation. ${ }^{5}$ Yet all three employ forms of worship subsequently called "natural religion," earth-centred, universalist, non-ritualistic, and tolerant versions of Christian faith focused on individuals rather than on abstract theology or a mysterious Creator-God to be worshipped from afar.

From the broadest historical perspective, both More and his followers seem jointly to respond to the discovery that the New World was not plagued by European-style religious warfare, a problem that their "new" if also primitive religions solve by discriminating against dissenters minimally or not at all. Moreover, the fact that gold held no intrinsic but only an extrinsic value for the New World natives, who treated it more or less like other beautiful, shiny objects, seems to underlie their basic agreement that the Western fetishization of gold unnecessarily promotes individual greed and economic warfare. ${ }^{6}$ Hence all three ideal societies instead pursue progressive collaborative knowledge, the opposite of the secret, mystical studies variously exploited by medieval sages. "Wonders" have not disappeared, not even in More, although both Bacon and Cavendish feature them in ways that often contrast with his utopian system. Setting More's Spartan or excessively plain and utilitarian principles aside, Bacon's priests and officials wear beautifully-coloured azure, green, and cobalt clothing, often with jewelled, velvet, or golden accessories, while his leading citizens are honoured with richly enamelled, solid gold grape clusters at their elaborate "Feast of the Family." Cavendish goes much further in creating a literally dazzling society so replete with gold, rainbow-hued diamonds, rubies, and other jewels that their value lies solely in their beauty, not in their exchange. However, as she explains,

None [of the citizens] was allowed to use or wear gold but those of the imperial race, which were the only nobles of the state; nor durst anyone wear jewels but the Emperor, the Empress, and their eldest son, notwithstanding that they had an infinite quantity both of gold and

5. On More's hybrid of Epicurean and Stoic ethics in Utopia, see Edward Surtz, The Praise of Pleasure: Philosophy, Education, and Communism in More's Utopia (Cambridge, MA: Harvard University Press, 1957).

6. Deng, 17, ff. 
precious stones in that world. [...] They used no coin, but all their traffic was by exchange of several commodities. ${ }^{7}$

Yet at the same time, her capitol city's buildings, clothing, and chariots are constructed of precious stones and metals for the apparent delight of all, although citizens trade through a simple barter system. Gold and jewels therefore have no exchange value but only the use-value to which More would confine them, although, obviously, their uses are diametrically opposite in the Blazing World.

Although Cavendish reserves the use of precious materials for purely functional structural, decorative, or defensive purposes, More's Utopians would clearly ridicule the Empress's addiction to lavish display as useless. Nevertheless, like the marble Augustus used to replace Rome's brick and create its imperial grandeur, her city's gold and jewels affirm the true greatness of her people. Their golden "architectures" are clearly designed to appear "noble, stately, and magnificent, not like our modern but like those in the Romans' time" (Cavendish, 259), public functions that would seem to exclude private avarice and promote only the aesthetic "greed" for beauty modelled by the supreme Empress. This entirely physical beauty is not metaphysical or Platonic, although it still signals the soul's ascent to a vision of splendour that enhances human pleasure and well-being. ${ }^{8}$ Here More's text again seems to lie in the distant background, for while he does briefly praise the Platonic contemplation of beauty and truth as a godlike mental pleasure, his implicit contrast is with the base commercial quest for gold. Hence Cavendish's superficially opposing treatment of the metal remains oddly utopian in essence if not in execution: beauty still supplies the supreme mental pleasure of wonder, which in the Blazing World is never for sale. Despite Bacon's very different uses and evaluation of truth-as-beauty, both the science and religion of his Salomon's House similarly promote physical wonder and well-being while rejecting all material reward.

The priest assigned to Bacon's charitable "Stranger's House" clearly explains that like his fellows in Salomon's House, he seeks only “a priest's reward:

7. Margaret Cavendish, The Blazing World (1666), in An Anthology of Seventeenth-Century Fiction, ed. Paul Salzman (Oxford: Oxford University Press, 2001), 250-348, 261. All further citations are from this edition and will be cited within the text.

8. See G. Gabrielle Starr, "Cavendish, Aesthetics, and the Anti-Platonic Line," Eighteenth-Century Studies 39.3 (Spring, 2006): 295-308. 
which was our brotherly love and the good of our souls and bodies." And like their counterparts in Utopia, all these priests worship the Creator chiefly through useful works that give him praise. They also teach ethics, not theology, not least because Bacon agrees with More that the limited powers of human reason can never ascertain the divine nature (More, 59, 61, 80-81). Here, as in his Advancement of Learning, Bacon uses this limitation to justify the "worship" of science defined as the beneficent discovery and practical imitation of nature's secrets, which God originally gave Adam to improve "man's estate." Thus, despite their many large and small differences, neither Bacon's nor Cavendish's utopia is remotely driven by gold either as a monetary reward or as a standard of exchange. The secular officials who preside over Bacon's imaginary capitol city, Bensalem (meaning "son or offspring of peace, safety, and completeness"), arrive in a partly "gilt" boat to signify their authority, but none will accept any gold for their services, claiming that doing so would mean that they were improperly "twice paid" (Weinberger, 46n68; Bacon, 39-40, 41). Their treatment of their bewildered foreign guests is astonishingly "gracious and parent-like," without charge of any kind, while they assure these lost sailors that their cargo will be freely stored and returned whenever they wish, "either in merchandise or in gold and silver: for to us it is all one" (Bacon, 45). Apparently, then, like Cavendish's citizens, they use some type of barter system in place of the gold standard, although gold here is optional, not banned. The type of pay given their priests and officials is nevertheless unspecified, and that, too, may not be monetary-they may receive payment in lands, charters, and emblems like those bestowed on the Father during Bensalem's "Feast of the Family," which honours fathers of any family producing at least thirty surviving members in several generations. Although the Fathers of Salomon's House are highly-trained knowledge specialists, their public service in distributing new, carefully-tested knowledge and inventions and in wisely settling disputes is also free.

Like More, however, Bacon provides an important exception to Bensalem's apparent antipathy to money, since a special class of technocrats called the "Merchants of Light" are employed to buy new "light," Bacon's metaphor for new information on "sciences, arts, manufactures and inventions of all the world." Yet as Bensalem's governor emphasizes, they trade "not for

9. Francis Bacon, "New Atlantis" and "The Great Instauration," ed. Jerry Weinberger. Rev. ed. (Wheeling, IL: Harlan Davidson, 1989), 46. All other citations of the New Atlantis are from this edition and are cited by page number in the text above. 
gold, silver, or jewels; nor for silks, nor for spices, nor any other commodity of matter; but only for God's first creature, Light: to have light [...] of the growth" of knowledge abroad (Bacon, 59, cf. 81). They thus apparently do exchange gold or its equivalent for this vital information just as the Utopians buy vital mercenaries with it. Some subterfuge is involved in both operations, because rather than employ mercenaries, the Utopians actually prefer to prevent war through false propaganda, sowing doubt and fear before their wars ever begin. Bacon's Merchants of Light instead hide their presence abroad by pretending to arrive from other nations (Bacon, 59). Some critics have considered this practice "industrial espionage," some call it imperialism or colonialism, but in practical terms it seems far closer to the self-protection More's Utopians achieve through rumour and outright deceit. In both cases, it prevents war and protects their peaceful states from envious encroachment by rival nations. ${ }^{10}$

There is, of course, no doubt that Bacon knew and admired More's Utopia, not least because he wishes to improve on the Utopians' pre-nuptial practices. Instead of taking the precaution of viewing prospective spouses nude to avoid what might politely be called extreme "disappointment," Bacon's Bensalemites gain similar knowledge from friends hidden in public baths for this purpose. To us this may well appear equally ludicrous, but both provisions partly rely on the understanding that the first marriage was literally in the nude, and Bacon's baths are specifically called "Adam and Eve's pools" (Bacon, 68). Nevertheless, Bacon's idealized families are not present in Utopia, nor is their natural moral perfection. Completely at odds with European forms of sexual exploitation-prostitution, fornication, marriage for money, buying mistresses,

10. Although this type of criticism goes back as far as Nietzsche and Heidegger, its primary modern source lies in Max Horkheimer and Theodor W. Adorno, Dialectic of Enlightenment, trans. John Cumming rpt. 1944 (New York: Continuum, 1969). Charles Whitney accuses Bacon's "Merchants" of industrial espionage in "Merchants of Light: Science as Colonization in the New Atlantis, in Francis Bacon's Legacy of Texts, ed. William A. Sessions (New York: AMS Press, 1990), 265-66, as does John Michael Archer in "Surveillance and Enlightenment in Bacon's New Atlantis", Assays 6 (1991): 111-12. Amy Boesky follows much the same tradition in describing Bensalem as imperialistic in Founding Fictions: Utopias in Early Modern England (Athens, GA: University of Georgia Press, 1996). For a counter-argument, see Catherine G. Martin, “The Ahistoricism of the New Historicism: Knowledge as Power versus Power as Knowledge in Bacon's New Atlantis," in Faultines and Controversies in the Study of Seventeenth-Century Literature, ed. Claude Summers and Ted-Larry Pebworth (Columbia: University of Missouri Press, 2002), 22-49. Leslie, in Renaissance Utopias and the Problem of History, repeatedly objects to this line of thought but in different terms and with different critics in mind. 
and adultery-Bacon's families are completely chaste. These sexual evils have also disappeared from Utopia through careful regulation, but Bacon alone directly and indirectly links them to the high value Europeans place on gold. Their total elimination in Bensalem is explained by an admiring Jew who also acts as an objective semi-outsider. He further suggests that the large families publicly honoured by its Feast of the Family have thrived through good nurture and moral education, for "those that are partakers of the blessing of that feast do flourish and prosper ever after in an extraordinary manner" (Bacon, 66), a use-value having nothing to do with money or class. Social disputes have of course not disappeared but are amicably resolved by the wise scientist-priests of Salomon's House, suggesting that as in More's Utopia, pride and other negative emotions have become negligible due to society's new collaborative structure, which in Bacon promotes both scientific advancement and prosperity.

Cavendish has nothing to say about nuptials and little about marriage beyond the fact that the males in her utopia "naturally" adore their wives, but she does acknowledge Bacon by creating her own version of his Salomon's House, a laboratory in which different specialists perform different types of research. Her specialists, however, are "beast men"-bear-men, ape- and fox-men, birdmen, fly-, fish-, or worm-men, and so forth-who transcend mere human knowledge by applying their species-specific skills and modes of apprehension to their tasks, thereby avoiding the need for mechanical instruments like the telescopes and microscopes that Cavendish held in great suspicion. In her view, real knowledge could only be unmechanically produced within the brains or senses of living organisms, and her Empress ultimately subjects all controversial opinions debated by her specialists to her own unique arbitration (Cavendish, 261, 268-72). These provisions may well parody the practices of the British Royal Society, which purported to model them on Bacon's fictional Salomon's House, but they also seem to support its basic divisions of labour into different types of research (Bacon, 81-82). The Empress's vastly superior military technology derives partly from these specialists but also partly from natural resources found only in the Blazing World: star stone and fire stone. Through her semi-mystical technology, she can and does unilaterally impose world peace through a devastating onslaught one might call total warfare. ${ }^{11}$ 
More's Utopians might aspire to such powers, but they are mere humans; like all strategies, their practices of buying mercenaries and secretly sowing fear and discord among their enemies sometimes fail. At that point, they are well prepared to enter battle both by training and by a residual honour code emphasizing military courage.

Courage is nevertheless a duty, not a cause for celebration, so it is neither materially nor ceremonially rewarded. Even the estates gained through their victories abroad are not granted to heroes or leaders but are run by state servants to supply future needs in the form of more mercenaries, more gold, or imported goods. As noted above, the Utopian work ethic assures regular surpluses of foodstuffs, hides, wool, and all other basic necessities, but Utopians also need gold to buy iron and presumably any other natural resources or commodities they lack. Here again, gold serves only the common good, not any individual profit motive, and otherwise Utopians militarily despise it for promoting false ideas of honour and prestige, causing wars, and exploiting civilian armies. Hythloday further clarifies their position in the passages surrounding the epigraph above, stressing that the Utopians never wage war for gain but only for defensive purposes when their own or friendly territories are unjustly invaded. ${ }^{12}$ Bacon's Bensalemites have so successfully hidden themselves from the world (an advantage aided by their natural geography) that they never need to engage in battle, but Cavendish's beast-man armies again recall More by following essentially the same principles Hythloday sets out: they wage war only to defend themselves or help others, never to enrich themselves.

Here it is important to note that Utopians' somewhat contradictory evaluation of gold as both useful and harmful does not actually upset their emphasis on its use-value; gold has its worth, yet as Christopher Kendrick observes, "it has not fallen under the spell of exchange-value, has not been reified to irrational ends" but always serves socially beneficial purposes determined by

12. Sir Thomas More, Utopia, trans. and ed. Robert M. Adams (New York: W.W. Norton, 1975), 26. All further citations are from this translation and will be cited within the text. Hythloday's remark is doubly ironic in that he truthfully says that all of a European king's counsellors recognize the interdependence of kingship, war, and gold, a truism attributed to Crassus by Cicero but partly refuted by Machiavelli. More's fiction at once supports and contradicts Crassus, since unlike Machiavelli, it approves of the use of mercenaries but disapproves of the false value placed on gold as well as on conquest. As Adams's note 6 on p. 26 explains, Crassus himself was partly refuted by his own assassination as molten gold was poured down his throat. 
collective decision-making. ${ }^{13}$ All such decisions reflect the Utopians' analysis of human "pride as the terrible suckfish that ruins European societies," which they counteract by "stripping pride of its milieu, [...] giving it no context, no realm of invidious difference in which to operate." Rather than an "ever-active force," pride is seen as the effect of unjust social relations and institutions, not an ineradicable "original sin" but an empty and preventable "phantasm projected by the European practice of private property" long since eliminated in Utopia along with the gold standard of exchange. ${ }^{14}$ These revolutionary ideas (presumably no joke even at the time) are not as clearly present in either Bacon or Cavendish, with the latter apparently endorsing pride as a natural and rightful corollary of imperial power. ${ }^{15} \mathrm{Bacon}$ is far more conflicted on this point, emphasizing the extreme humility that allows the Fathers of Salomon's House to advise citizens wisely and to benignly exercise their power and influence, while they at the same time prove not only that knowledge is power in an institutional sense, but that great wealth and happiness are its result. ${ }^{16}$ Cavendish's utopia again differs even further insofar as its fabulous wealth is less the result of its knowledge economy than of its astounding mineral resources, but like both her predecessors, her Blazing World's perfection still depends partly on its sage sovereign (or founder in both More and Bacon) and partly on the knowledge specialists who run it.

13. Christopher Kendrick, Utopia, Carnival, and Commonwealth in Renaissance England (Toronto: University of Toronoto Press, 2004), 67.

14. Kendrick, 59.

15. There is no room here to discuss the long and well-known tradition of regarding Utopia as simply a joke or satire; despite its many ironies, it can and should be taken to represent an ideal society. See J. C. Davis, Utopia and the Ideal Society: A Study of English Utopian Writing, 1517-1700 (Cambridge: Cambridge University Press, 1981).

16. Bacon's "In Praise of Knowledge" is often oversimplified on this point. Sovereigns should promote knowledge, but they can do so only by subjecting themselves to its requirements, which are closely linked to holistic human sovereignty over nature: "the sovereignty of man lieth hid in knowledge; wherein many things are reserved, [so...] kings with their treasure cannot buy [it], nor with their force command [it]; their spials and intelligencers can give no news of them, their seamen and discoverers cannot sail where they grow." Knowledge in this sense remains distinct from power; while power is subject to knowledge, knowledge is not subject to power. See The Works of Francis Bacon, ed James Spedding, Robert Leslie Ellis, and Douglas Denon Heath (London: Longman and Co, 1859), 123, 125, and my essay, "The Ahistoricism of the New Historicism." 
To accurately sort out all the most important departures from More in Bacon's and Cavendish's later utopias along with the reasons behind them, a closer analysis of their "original" is first in order. As noted above, at a structural level More's two preeminent literary successors largely accept his analysis of the destructive and closely intertwined problems caused when gold is the chief or only standard of value: competition, economic ambition, and plutocratic pride. While both later utopias certainly do possess and value material treasures far more than More's Utopians do, there is surprisingly so little if any economic rationale for their existence that most seem to qualify as "wonders" rather than as necessities. Salomon's House is virtually a curiosity cabinet of astounding inventions, while the Blazing World is a kind of living, breathing "El Dorado" set in an alternate universe armed with super powers. Those facts lead us to ask what comparable "wonders" More's Utopia exhibits and whether they consist largely in his radical transformation of human nature, especially his eradication of the competitive drives fueling most societies, along with the resultant pride and fear. Yet startling moral transformations are also evident in his followers' utopias. Bacon's people are super-humanly chaste, while his Merchants of Light are super-humanly selfless in seeking neither luxury goods nor gold. Bacon in fact regarded all such goods as lesser "Fruits" than "Light," "fruits" meaning to him quick but illusory profits that too often eclipse the greater but less obvious benefits of knowledge. True to her staunch royalist yet also anti-commercial principles, Cavendish similarly disdains quick profits and far more literally seems to worship "Light." A diamond-lit brilliance surrounds both her Empress and her entire world, although it never directly advances knowledge or the common good, as More and Bacon would require. Light in the form of star stone and fire stone nevertheless provides a preeminent advantage in subduing the enemy and securing peace, so ironically, both later utopias essentially retain More's ethic of faithfulness to Nature and her true or essential "goods," a safe, healthy, enlightened, and stable society founded on strong families. The main difference is that Cavendish's fantasy instead features Platonic love and friendship between and among the sexes, while both she and Bacon add the prolongation of life to More's goal of health. Her Blazing World possesses regenerative golden sands rather than the golden or scarlet-orange fruits that Salomon's House has apparently bred to cure all ailments, but these semi-magical elements are absent from Utopia. 
More in general differs by eschewing such "romantic" wish-fulfillments, and his society is neither aesthetically nor technically splendid like the other two, featuring no mechanical or military marvels. In addition, he is far more attentive to the family as a practical organizational and disciplinary unit than as a fantasy ideal or Platonic romance, while his emphasis on health mainly focuses on individuals. His Utopians explicitly identify health as the supreme form of physical happiness, but one "unmagically" to be gained only by giving up private property, the ultimate source of competition for basic goods and thus of malnutrition and disease for many. Hythloday's detailed description of Utopia's organization generally makes its well-being far more rationally explicable than anything in Bacon or Cavendish, clearly linking it to short work hours, healthful communal meals, and the total elimination of all forms of poverty through the abolition of private property. Moreover, ultimate happiness here is still reserved for the afterlife, and while Cavendish's Empress agrees on the moral stimulus of hoping for heaven and fearing hell, like Bacon she creates her own version of a virtual heaven-on-earth. ${ }^{17}$ More's severe separation of "pure" pleasure from material things is also far more traditional, emphasizing as he does the cultivation of the soul and its progress toward heaven. Materialism is at once advocated and considered spiritually dubious on economic grounds, in part because if physical beauty can be competitively manufactured and displayed through such arts as dyeing (a process the Utopians never use), then it can become the kind of proto-capitalist status symbol that they reject in advance. Their simple, natural wool and leather clothing could hardly contrast more with the brilliant dress of More's successors, both of whom endorse gold ornamentation.

In economic actuality, however, there is really nothing sacred about the gold standard, which in itself does not create materialism. In addition, many advanced trading economies have managed quite well without it, and the highly capitalized late nineteenth-century American economy witnessed attempts to supplement gold with silver long before (in America, in 1971) the gold standard was finally abandoned. ${ }^{18}$ More's foundational antipathy to gold

17. Bacon's lost sailors cannot decide whether they have arrived in a land of magicians or angels, but Bensalem's governor assures them that while their healing powers are "divine," natural causes are at work (Bacon, 46, 51).

18. See James Ledbetter, One Nation under Gold: How One Precious Metal Has Dominated the American Imagination for Four Centuries (New York: Liveright, 2017). 
thus seems to rest on partly spiritual considerations, in this case drawn from the Bible's condemnation of the god "Mammon" and Christ's warning against the "treasure [...] that corrupts" (Matt. 6:19). Like Isaiah, Christ never tires of castigating the "valueless gods of gold" (Isaiah 2:20, 31:7) as false Idols. For More, these condemnations were confirmed by the contemporary situation, where wealthy landowners were rapidly displacing the poor from their commonly held land through the then-profitable practice of enclosure. ${ }^{19}$ These profits were gained through legal tender or the common currency, but since they depended upon the import/export industry, they too depended upon the gold standard and therefore increased More's antipathy to the corrupting metal. More's Christian bias against gold becomes particularly apparent when Hythloday discusses the "gods of greed," a passage in many ways looking forward to Edmund Spenser's portrait of Mammon in the second book of The Faerie Queene. Not only does Hythloday find gold fever as innately irrational as worshipping natural shiny objects like gems, but he makes gold responsible for closely related misuses of fine clothing, titles, and the social deference that accompanies them.

The love of rare gems is perhaps the most absurd of all, since men go to great lengths to ensure their jewels are authentic when a beautiful counterfeit would actually provide as much pleasure. That means that their owners are far less interested in physical beauty than in the status of being able to buy rare gems, which in turn testifies to the power of accumulation and why the human delight in "mere money" finally tops the list of empty vanities. As Hythloday adds, men

[...] pile up money, not because they want to do anything with the heap, but so they can sit and look at it. [...] Or what of those with the opposite vice, the men who hide away money they will never use and perhaps never even see again? [...] And yet when the miser has hidden his treasure, he exults over it as if his mind were now free to rejoice. Suppose someone stole it, and the miser dies ten years later, knowing nothing of the theft.

19. For more details, see Karl Kautsky, “The Roots of More's Socialism," in the Adams translation of Utopia cited above, 140-48, especially 146, originally printed in Kautsky's Thomas More and His Utopia, trans. H. J. Stenning (New York: A. C. Black, 1927), 159-71. Other early More scholars come to much the same conclusion. 
During all those ten years, what did it matter whether the money was stolen or not? In either case, it was equally useless to the owner. (More, 58)

The lack of use-value at the heart of mercantilist or capitalist accumulationfor-its-own-sake leads Hythloday to condemn other unproductive or cruel pleasures such as gambling, hunting, and hawking. Gambling is a supremely wasteful form of greed (wanting something for nothing, or buying low and selling high), while barbaric hunters enjoy "the killing and mutilating of some poor creature" merely due to pride in their ability to destroy it (More, 58). His Utopians are not vegetarians, but they reserve all necessary slaughter and butchering for slaves, who are mostly criminals paying for their crimes. These remarks establish a close link between "treasure" (money, gold, or jewels) and crime, including needless or exploitative bloodshed. Cavendish and probably Bacon share these conclusions. Bacon's Bensalemites are naturally protected from violence by a combination of perfect laws and geographic isolation from greedy, marauding nations. Cavendish does not discuss hunting or other forms of unnecessary cruelty in The Blazing World, but her sympathy with hunted animals and general antipathy to the sport is abundantly clear in perhaps her best poem, "The Hunting of the Hare."

More attributes his startling inversions of the European status quo to his founding King Utopos, who began abolishing common customs and values by proclaiming that differential status could no longer accrue from either selfish material accumulation or conspicuous consumption. Good citizenship and scholarship would be rewarded with leadership but not money or gold, while all citizens were required to value only the usefulness, not the specious prestige afforded by material objects and elite activities. This drastic change-unheard of in even the most primitive societies, whose leaders typically belong to and display the external symbols of a warrior elite-required deep alterations in what seem to be humanity's innately aggressive and accumulative instincts. More thus comes down strongly on the "nurture" side of the debate about human nature, and his heirs silently follow suit as they drastically reorganize their societies along new economic, scientific, or feminist lines. Edward Surtz finds More's wholesale alterations at least partly believable because he does not eliminate the "pleasure principle" but reorients it along neo-Epicurean lines, so that all or most simple physical gratifications are understood as good and 
all excesses as bad or unhealthy. ${ }^{20}$ This state of affairs of course only becomes possible once all basic human needs have been met, including the more abstract intellectual and aesthetic need to pursue, refine, and increase learning and craftsmanship of all kinds. The qualifier is that all forms of aesthetic production formerly associated with high status must now be considered excessive and unnatural, and therefore become literally ludicrous from the austere Utopian perspective.

More's attitude toward military glory is equally austere, stemming from his opinion that nothing is "so inglorious as the glory won in battle" (More, 71). He somewhat contradicts his own point by portraying the Utopians as staunchly heroic in the last instance, when whole families including their able-bodied females fight side by side to reinforce their nation's "death before dishonor" code and win their wars (More, 75), but since every effort is taken to prevent this instance, it must only rarely occur. The Utopians in fact highly value peace in every aspect of their lives, including religion. More's wise King Utopos discovered in advance that religion is always potentially the most divisive factor in society, and according to Hythloday, the reason is that the "worst" kind of people are often prone to violently enforcing their own opinions while restricting all others. Years later, the Utopians still adhere to their Founder's reasoning by securing almost complete religious toleration for their citizens. Raphael reports that on a recent visit, the "new" religion of Christianity has been welcomed, but any divisive preaching still remains "foreign" and ultimately forbidden (after gentle attempts at persuasion). Most Utopians nevertheless recognize the strong resemblance of their basic beliefs to Christ's teaching, especially on communal property and brotherly love, but the only belief they enforce is on the immortality of the soul. As usual, they approve it more for practical reasons of morality than theology; although this belief rightly recognizes mankind's divine nature and superiority to beasts, it

20. Unlike Epicurus himself, however, More emphasizes doing no harm to others along with the superiority of mental to physical pleasures, although both are good provided they do no hurt, as Surtz explains (30). He seeks, more precisely, to reconcile Stoic and Epicurean definitions of the good by arguing in the following way: "Virtue is life lived according to nature. But life lived according to nature is the selection and rejection of things according to reason. But reason advises and incites us to lead a life as free from care and full of joy as possible, and to show ourselves helpful, in view of the fellowship arising from nature, in obtaining the same for all other human beings. Therefore virtue advises and incites us to lead a life as free from care and full of joy as possible" (20). 
also encourages the observance of laws that might be violated with impunity if divine punishment did not exist.

Disagreement with this universal belief seems so irrational to Utopians that it is as rare as it is disgraceful, not least because human immortality and divine judgment both require a just God who fairly metes out eternal rewards and punishments (More, 80). Despite their religious diversity, then, all, "even the most diverse, agree in the main point, which is worship of the divine nature; they are like travelers going to one destination by different roads. So, nothing is seen or heard in the churches that does not square with" the essential teachings of "all the creeds," and no church contains any image of God so that each participant can form her own personal portrait of him (More, 85-86). In other words, they allow no real competition in religion any more than in money, and "the priest and the people together recite certain fixed forms of prayer, so composed that what they all repeat in unison each individual can apply to himself" in his or her own unique way (More, 87) while believing all are in fundamental agreement. Men are seated on one side of the church and women on the other, in part so mothers can supervise their daughters' and fathers their sons' behaviour (More, 86), and in part because gender differences seem innate. Cavendish does not really disagree with that, either, but she of course makes women superior. As noted above, Bacon does not need to consider warfare, but More's and Cavendish's equally strong condemnation of war stems from their strong agreement on its causes: avarice for gold stimulated by trade and its nationalistic human equivalent, princely ambition and acquisitiveness.

As Hythloday early observes in More's Utopia, "most princes apply themselves to the arts of war [...] instead of the good arts of peace. They are generally more set on acquiring new kingdoms by hook or by crook than on governing well those that they already have," or in defending their homelands as both the Utopians and Cavendish's Empress strenuously do. He goes on to remark how the rich closely resemble princes in ignoring sound agriculture and instead wallowing in "crass avarice" and "wanton luxury" at the people's expense (More, 10, 15). It further follows from the fact that "a king who wants to maintain an army can never have too much gold" that, in acquiring it, he "can do no wrong, for all property belongs to the king," not the people. Kings actually benefit from allowing subjects as little wealth as possible, for "riches and property make men less patient to endure harsh and unjust commands," which the poor accept because their oppressed condition blunts their spirits. 
While avarice may be rooted in fear of poverty as well as in pride, both vices produce the many superfluous trades invented to display wealth and inspire awe (More, 26, 45-46, 42).

Cavendish's completely opposite attitudes toward wealth, ornamentation, and display would seem to deny any possible influence by More, as would her repeated claims of almost complete originality. These claims cannot be denied, stemming as they do from her lack of the humanistic formal education shared by More and Bacon. Yet the little poem set into the frontispiece to her Philosophical and Physical Opinions (which precedes by more than a decade her Description of a New World, called the Blazing World) is on the whole a defensive overstatement:
Studious She is and all Alone
Most visitants, when She has none,
Her Library on which She looks
It is her Head, her Thoughts her Books.
Scorninge dead Ashes without fire
For her own Flames do her Inspire. ${ }^{21}$

The same work nevertheless features her well-known interest and extensive reading in natural philosophy, especially the atomist and materialist speculations popular at the time. She admits to having read at least some of Hobbes's De Cive and Descartes's theory of the passions, along with diverse works of "fancy" or imagination that helped inspire her "own Flames." How well or directly she knew More's Utopia is less certain, but she was clearly familiar with the philosophical traditions it sprang from, and as we have seen, her Blazing World directly engages with both Bacon's New Atlantis and the later seventeenth-century Baconians, whose ideas she partly accepts and partly satirizes throughout. ${ }^{22}$ 
A further objection might be that some critics have regarded Cavendish as inverting or even ridiculing More as well as Bacon, but as outlined above, her actual strategy is idiosyncratically to select what to conserve along with what to parody or omit. Most obviously, of course, she overturns the socialist/ communist foundations of More's Utopia and replaces them with an absolutist, imperialist state. Yet like More's ideal society, her Blazing World responds to the growing competition within and between European nations-itself fueled by trade based on the gold standard-by minimizing or eliminating it. More himself would overturn the growing power of both the English landholding classes and their monarch, while Cavendish imagines a non-competitive, distinctly feminist version of world monarchy. ${ }^{23}$ These contrasts are nevertheless far more political than economic, since neither mercantilism nor capitalism contributes to the power of her imaginary state, which strangely follows More in substituting gold use-value for gold exchange value. The only merchant who appears in Cavendish's utopia is a selfish kidnapper who immediately and justly perishes after inadvertently transporting the future Empress to the Blazing World. Its Emperor falls in love with the lost lady at first sight, marries and transfers all power to her without the least hint of financial gain. This incident hardly constitutes anything like More's "brutal critique" of protocapitalist accumulation or investment, but it just as effectively puts an end to it. ${ }^{24}$ Once again, Europe's economic and religious warfare is replaced by a united community having only one language, religion, and ruler, none of which would be feasible without eliminating economic and other forms of competition. ${ }^{25}$

Although Cavendish read Hobbes and similarly endorses unlimited sovereignty, she shares none of his enthusiasm for royal absolutism as the best means of promoting a mercantilist expansion of industry and exportation. Instead, she imagines a wholly self-sufficient royalist monopoly utterly at odds

but satirically turns Bacon's knowledge specialists into various kinds of "beast-men," which nevertheless prove so useful that Cavendish's satire blends with her fantasy.

23. See Rachel Trubowitz, "The Reenchantment of Utopia and the Female Monarchical Self: Margaret Cavendish's Blazing World,” Tulsa Studies in Women's Literature 11.2 (Fall 1992): 229-46.

24. Kendrick, 37.

25. I refer to the standard analysis of the rise of republican government from economic competition and the need to represent competing interests. Technically, Cavendish's Empress cedes Europe to her former homeland, ESFI (England/Scotland/France/Ireland), and does not directly govern it, but it still seems to be a satellite state of the Blazing World; see below. 
with England's commercialized monarchy at the time or in any near future. Kendrick describes More's Utopia as in some sense a "mercantilist fantasy" of total economic control, but unlike Hobbes's Leviathan and like Cavendish's Blazing World, "it is intended to discourage absolutist ventures" on the part of any but a fully self-sufficient state. ${ }^{26}$ The chief underlying reason for their consensus seems to be that both agree that commercial society undermines the traditional values of virtue, honour, community, peaceful intellectual exchange, and overall social and physical health. In More's analysis, by enabling commercial trade, the gold standard distorts the economy as a whole, which further explains why religion plays such a key role in all the utopias he influenced. Stressing social harmony and community while discouraging individual accumulation, competition and envy, religion combats the evils More's ideal state was designed to eliminate. To further enable this harmony, the leaders of all three utopias are also virtually the same: the wisest, best educated, and least selfinterested citizens, although Cavendish's Empress is also the most dazzlingly beautiful and "justly" proud. Like the Fathers and officials of Bensalem, she rejects More's resistance to beautiful display but also partly follows him insofar as her grandeur signifies not wealth but virtue, and social prestige based on merit, not inheritance. Much as Cavendish valued her aristocratic lineage and the native worth it supposedly conveyed, her Empress achieves her status solely through innate and not inherited merit. She is initially a complete stranger in the Blazing World, possessing only an outward beauty that seems also to reflect feminine values traditionally associated with fine arts and crafts. Her own worth, however, mainly consists in overwhelming her masculine enemies-again, partly through magnificent display-and overturning the specious opinions of the scientific specialists she loosely borrows from Bacon's Bensalem. Yet at the same time, much like More, she largely reserves social prestige for knowledge production, divine worship, and charitable works. Even the Empress's "divine" beauty is not acquired or enhanced by any artificial methods, and she actively ministers to her people just as Bacon's priestly caste actively ministers to theirs.

Part of the Empress's "ministry" is religious, but the major part is military, and there her critique of standard European motives and practices most closely resembles More's analysis. She bitterly complains that even though "there were so many several nations, governments, laws, religions, opinion, etc," people are 
never satisfied because they are commonly "ambitious, proud, self-conceited, vain, prodigal, deceitful, envious, malicious, unjust, revengeful, irreligious, [and] factious." Few have ever been "contented in their own shares," but have instead "endeavoured to encroach upon their neighbours," thinking "their greatest glory was in plunder and slaughter, and yet their victories [were] less than their expenses, and their losses more than their gains." Thus, absurdly, they "value dirt more than men's lives, and vanity more than tranquility (Cavendish, 315). For Cavendish as for More, "vanity" here very clearly includes gold in the form of money, whose possession inevitably leads not only to the loss of tranquility but at times even to madness. As for her city's massive golden architecture, that could never easily be exchanged or melted down. The quoted remarks above appear late in the text, but they support everything that has gone before and clearly connect her to More's Utopians. Her total victory over her homeland's enemies is not memorialized with gold or brass monuments and she refuses to use gold to enrich her own countrymen. Her rationale, as she tells the fictional Duchess of Newcastle, is

\begin{abstract}
"Much gold and great store of riches makes them mad, insomuch as they endeavour to destroy each other for gold or riches' sake." "The reason thereof is," said the Duchess [Cavendish] "that they have too little gold and riches, which makes them so eager to have it." "No," replied the Empress's soul, "their particular covetousness is beyond all the wealth of the richest world, and the more riches they have, the more covetous they are, for their covetousness is infinite. "But," said she, I would there could be a passage to be found out of the Blazing World into the world whence you came, and I would willingly give you as much riches as you desired" (Cavendish, 340-41).
\end{abstract}

Yet the Duchess-Cavendish appearing as herself-is a quick study. She assures the Empress that she herself is not avaricious and that she wishes only to restore her husband's losses in the civil wars, not for his own sake but for his posterity. The Empress replies that she will command her fish-men to find out a passage between their worlds to repair those losses, but the Duchess demurs: she would much prefer her Highness's golden sands to real gold or jewels, since their ability to prolong and renew life far exceeds any material wealth. The Empress agrees but somewhat oddly doubts that any such passage can be 
discovered, even though her submarines and fish-men have already navigated it. This doubt nevertheless allows her to offer Cavendish a monarchy as great as her own, but she again modestly declines, saying that she "esteems her love beyond all things that are in nature" (Cavendish, 341), perhaps because Platonic love (unlike other "goods") possesses only use value.

As we have seen, More's Utopians are equally utilitarian in their warfare, never condoning "ambitious" violence or territorial aggression, but fighting as efficiently and bloodlessly as possible to defend themselves or their friends. Cavendish is less consistent about military glory, however, and her Empress actually welcomes it after successfully defending her former homeland, ESFI. She then appears in literally blazing majesty as a great saviour, but not as a self-interested aggressor: the "Empress did not only save her native country, but made it the absolute monarchy of all that world, and both the effects of her power and her beauty did kindle a great desire in all the greatest princes to see her" (Cavendish, 338). Hence her personal reward for uniting these former enemy princes lies in granting their desired audience in a scene that can only be described as an apotheosis. In garments and hair ornaments made of precious gems and star stone, she causes such "great admiration in"

all that were present, [...] they believed her to be some celestial creature, or rather an uncreated goddess, and they all had a desire to worship her, for surely, said they, no mortal creature can have such a splendid and transcendent beauty, nor can any have so great a power as she has, to walk upon the waters and destroy whatever she pleases, not only whole nations but a whole world. (Cavendish, 339)

Yet once again, her jewels and the power of her starlight are not mere prideful or idle treasures but useful tools in impressing her enemies and uniting the world. And while all powerful, the Empress is also benevolent insofar as she has used her fire stones to astound or warn both friends and enemies, but whenever possible, she refrains from destroying the aggressors. Like the public warning notices the Utopians use to discourage or forestall potential attacks, the Empress's fire stones and their partly illusory flames prevent greater harm, and she even dims their terror when it becomes too overwhelming. She unleashes their full destructive power only when enemy cities and ships stubbornly resist her, but even then, "she was loath to make more spoil than 
she was forced to" (Cavendish, 337). The Empress's military weapons further include the outright trickery employed by Utopians but intended in both cases only to save lives. To her homeland she "was an angel sent from God to deliver them" from unjust assault, and God himself justifies her intervention on their part, as she announces (Cavendish, 335):

Great, heroic, and famous monarchs, I come hither to assist the King of ESFI against his enemies, he being unjustly assaulted by many several nations which would fain take away his hereditary rights and prerogatives of the narrow seas, at which unjustice heaven was much displeased, and for the injuries he received from his enemies, rewarded him with an absolute power, so that now he is become the head monarch of this world, which power though you may envy, yet you can no ways hinder him, for all those that endeavour to resist his power shall only get loss for their labour and no victory for their profit. Wherefore my advice to you all is to pay him tribute justly and truly, that you may live peacefully and happily, and be rewarded with the blessings of heaven, which I wish you from my soul. (Cavendish, 340)

Since God's voice is not heard in this matter and the victory really belongs to the Empress's supernatural weapons, her speech comes across more as a highminded form of bribery than as Utopian mercy, especially as the assaults on ESFI's shipping and trading rights clearly recall the bitter competition behind the contemporary Anglo-Dutch wars. Yet the episode as a whole also recalls the Utopians' ultra-pragmatic Machiavellianism, particularly as the Empress similarly employs mercenaries. The Utopians' opinion of "war [as] an activity fit only for beasts" includes deep disdain for the vicious, partly subhuman "Zapoletes" they hire, while the Empress employs literally subhuman bear-, bird-, fish-, and worm-men to do her bidding. Yet she has no need to bribe them since they serve freely and, unlike the Zapoletes, they seem to suffer no losses. That fact adds to the glory she, like More, elsewhere rejects, but her "glorious" war still ironically conforms to most Utopian principles. According to Hythloday, Utopians "go to war only for good reasons," protecting their own lands or their friends from foreign invasion, although sometimes to "avenge previous injuries." These injuries include being plundered or made subject to extortion, but like the Empress, Utopians intervene only when the injured parties 
request it (More, 71). They are similarly reluctant to gain too bloody a victory, preferring instead to surprise the enemy by "skill and cunning." The Utopians do erect great memorials to successes of this kind, but not to more violent ones (More, 72). After the enemy's defeat, both nations make honourable truces that they never violate, nor do they unnecessarily despoil the lands or crops of the defeated, although they do collect the costs of the war from them. The Utopians use that money to finance future wars or gain landed estates to help subsidize further defenses. Finally, again like the Empress in advance, Utopians avoid waging war on their own territory but strongly attack their opponents abroad, making their victories swift, efficient, and as innocuous to both sides as possible (More, 77-78).

For More, these practices constitute the essence of "civilized" warfare, and while the Empress's victory is far more truly fantastic, she takes essentially the same approach: war is a necessary evil, although Cavendish clearly delights in the lavish glory tantamount to worship achieved by her imaginary "Amazon." More obliquely, she follows More by using gold to conduct her Empress's warfare while at the same time devaluing it. Yet instead of using gold for chamber pots and slave fetters, Cavendish reserves it for stealth weapons and for the "dust" laid down in the royal stables, a usage every bit as humble (or more so) than chamber pots (Cavendish, 343). ${ }^{27}$ The Empress also employs golden submarines guided or drawn by her fish-men with golden chains but painted black to make them invisible to even the best telescopes. She thereby achieves a surprise attack more overwhelming than any Utopian could hope for, especially as there are neither any civilian nor "beast-men" casualties (Cavendish, 332-33).

Finally, as suggested above, all three utopias employ a priestly caste, but in Bensalem there are no churches or formal places of worship, which helps their priests model the supreme Bensalemite virtues of humility, tolerance, and charity. ${ }^{28}$ Their founding role has been to certify the miracle that Christianized

27. The stables themselves are also literally precious, made of gold and arched with agates, jewels, and crystal, which leads to the conclusion that the "golden sands" mentioned here are real gold dust and are not merely golden in colour.

28. As Moody Prior summarizes, Bacon's pragmatic "identification of scientific truth with use and therefore with charity, with power and therefore with pity, is fundamental to Bacon's concept of true learning"; and as Jerry Weinberger adds, this learning is boundless because like "charity[, it] knows no excess." Moody Prior, "Bacon's Man of Science," in Essential Articles for the Study of Francis Bacon, ed. Brian Vickers (Hamden, CT: Archon Books, 1968), 147; and Jerry Weinberger, Science, Faith, and 
their nation, bringing an ark containing the entire Bible to their shores, its location illuminated by a pillar of light crowned with a cross (Bacon, 47). Yet they have built no monument to its arrival either at sea or on their shore, thereby limiting their own function to biblical interpretation and teaching, apparently without any element of ceremonial commemoration or communal sacrifice. The claim is sometimes made that the Fathers of Salomon's House have "staged" this miracle to advance their own prestige and gain more control, but the fact that all of Bensalem's multi-lingual population can and do individually read the Bible in their own tongue further confirms it. More's and Cavendish's priests on the contrary do preside over churches-in More's case, the only beautifully adorned objects besides his priests' own feathered robes, products of birds and not precious metals or dyes-and as noted above, they also conduct simple non-denominational prayer services to which no rational believer in a benign Supreme Power could (or does) object. ${ }^{29}$

Like Bensalem's priests, More's holy men are called "fathers" (More, 85, 87), but there most similarities end, because despite their similar emphasis on truth as far better than gold, they play no role in scientific research. Yet here, too, the differences are more superficial than they initially seem. It seems no accident that their God remains as essentially inscrutable as Cavendish's deity, for in all three utopias he is not an object of abject self-surrender but a reason to believe in the divine soul's self-improvement through superior nurture. All three authors believe that God has already implanted clear distinctions of right and wrong in human nature, along with the belief that good will be rewarded and evil punished in the afterlife (cf. Cavendish, 262, 294), a belief closely tied to the "use-value" of natural religion. All three also indicate how their lands' original religions have been beneficially reformed by further revelations, insights, or improvements based on the fundamental truth expressed by Cavendish's newly crowned Empress: "though there were several sorts of men, yet had they all but one opinion concerning the worship and adoration of God," which is to "unanimously acknowledge, worship and adore the only,

Politics: Francis Bacon and the Utopian Roots of the Modern Age (Ithaca, NY: Cornell University Press, 1985), 292.

29. More's churches exhibit the most ceremonial and "Catholic-seeming" version of religion, featuring hymns and the burning of candles and incense, but no Catholic Mass since they are not even officially Christian (86-87). The emphasis thus falls on social unity and sublime awe, not sacrifice or selfhumiliation, which can themselves become the focus of competition. 
omnipotent and eternal God with all reverence, submission and duty." To accommodate differences, their ceremonies are highly simplified, and to avoid theological disputes over technicalities, they stress highly practical "prayers, which we frame according to our several necessities in petitions, humiliations, thanksgiving, etc" (Cavendish, 262, 289).

Women in the Blazing World were not initially included in worship, an omission the Empress soon corrects by giving them their own congregations, an arrangement perhaps suggested by the fact that Utopia earlier opened its priesthood to women (More, 84). The Empress then goes a step farther and converts her people to her "own religion," presumably Christianity, though that is never stated. Yet as she soon finds, their conversion is initially unsatisfactory because human opinion is inconstant and, like the dissenting sects originally encountered by King Utopos, people soon abandon agreement because they favour their own "fancies and [...] desires." However, the Empress's solution to this problem is even simpler than the open-ended common prayers recited by the Utopians. Using the native fire stone and also star stone brought to her by her bird-men, she builds two chapels, one vividly depicting hell's flames and the other the "splendor and comfortable light" of heaven. In each chapel respectively, sermons preach the punishment of sin and the comforts of repentance, and by this method, as in Utopia, where heretical denial of immortality is similarly not fined but strongly discouraged by rational persuasion, citizens remain in a "constant belief without enforcement or bloodshed." Knowing that belief can only be instilled by "gentle persuasions" that encourage faithfulness to good "duties and employments," the Empress stresses love over fear, for though it makes people obey," fear does "not last so long nor is it so sure a means to keep them in their duties as love" (Cavendish, 290-91). Most moderns would not consider terrifying warnings of hell "loving," but for early moderns any nonviolent means of preventing eternal torment would qualify as a practical "usevalue" of true religion, something "mere" ornament is not. Here Cavendish implicitly concedes that "all that glitters is not gold," except perhaps the golden rule, which "shines" in a very different way, although she hardly believes that gold or iron should be melted down into plowshares any more than that she should relinquish her fire and star stones.

More's and Bacon's communities generally apply the golden rule far more literally than Cavendish's imperial Highness does. More constructs a scholarly paradise where self-made intellectuals benignly lead society and eliminate 
both excess wealth and poverty, while Bacon constructs a scientific paradise led by discoverers and inventors who provide charity, health, useful scientific inventions, prosperity, and (one must assume) greater convenience for all. Cavendish doubtless shares most of their humanistic principles, including their common abhorrence of violence and injustice, although she achieves them through regal privilege and feminine virtue. Yet like the others, hers is a "compensatory" narrative where the author poses as an outsider with astounding "insider" friends: just as Cavendish has her Empress, Bacon has the chief Father of Salomon's House, and More has his Hythloday, his own alter-ego like the rest. It goes without saying that not just the disgraced Lord Chancellor but the overly "singular" Duchess of Newcastle and the subsequently martyred More had strong real-life reasons to invest in their privileged counterparts, although concrete comparison suggests that More remains the most realistic fantasist. His chief "wonder" is a socially engineered transformation of human nature from its selfish, competitive, and materialistic roots to a more "original" Adamic condition. Although transferring all violence to various kinds of slaves or hirelings hardly seems Edenic, now or then, his society has real criminals and real enemies, neither of which Bacon accounts for, although he might well have done so had he had time to finish his fragmentary New Atlantis. Like More, he emphasizes family units that Cavendish excludes, although her feminist paradise remains as appealing to many as More's socialist and Bacon's technocratic ideal states. True, Bacon's naturally "virginal" people are as improbable (Bacon, 66) as More's incredibly unselfish and disciplined Utopians and Cavendish's perfectly beautiful and invulnerable Empress, but the appeal of worlds uncontaminated by money or lust and invested in gold only as one among other beautiful things has never ceased to exert a strong attraction for idealists. Moreover, as Marina Leslie points out, expecting utopists to outline real life solutions to intractable human problems asks too much of the utopian genre. At best, utopianism is an imaginative meditation on our history and our irrepressible hopes to better it, not merely a practical or impractical dream. ${ }^{30}$ And without this kind of writing, which, in every example considered here, pinpoints fundamental contradictions in the Western value system and its ostensibly Christian ideals, our literature would be far poorer and far more tarnished by all that glitters. 